\title{
b) 混融試看
}

・兩者を略同量に取りよく混和したるものにつき混融試羷をなすに約 190 ににて 發泡分解す。

c) 亏セ $i$ 化

各 $0.0219 \mathrm{~g}$ を科取混合しノルコホルに溶解して $10 \mathrm{cc}$ となし $1 \mathrm{dm}$ の管にて旅 光度を測定するに $[\alpha]_{D}^{n 00}= \pm 0^{\circ}$ を得たり．但し物質僅少なりしを以て 雨者の混 溶液を浱縮して全く一樣なる結晶性物質を得て之につき旋光度の測定をなし得さ りしを遺撼とす。

（昭和二年九月五日乙卵研究所にて酳も）

\section{ロイシン及びチロシンの脫炭酸作用に就て}

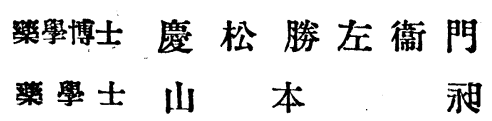

S. Keimatsu und S. Yamamoto: Zur Decarboxylierung von Leucin und Tyrosin.

ロイシンの脫炭酸作用 Decarboxylierung に關してはリンプリヒト Limpricht $\mathbf{1}_{\text {十 }}$ シュワーネルト Schwanert ${ }^{2}$ ) 兩氏がロイシンの高熱に對する反應を研究せるに 始まれり．兩氏は單に乾燥せるロイシンを油浴中に加熱せるに $170^{\circ}$ 位より暙融 し始め $180-184^{\circ}$ 位にて分解蒸溜行はれ受器には黄色脂肪油狀にしてアムモニ 臭おる液を得たり.

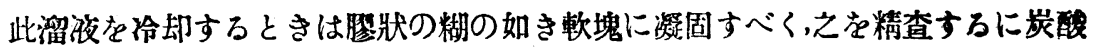
イソ.アミルアミンに外ならさるを知れり。即ち此祭の反應は

$$
\mathrm{CH}_{3}>\mathrm{CH}-\mathrm{CH}_{2}-\mathrm{CH}\left(\mathrm{NH}_{2}\right)-\mathrm{COO}: \mathrm{H} \rightarrow \mathrm{CH}_{3}>\mathrm{CH}-\mathrm{CH}_{2}-\mathrm{CH}_{2}-\mathrm{NH}_{2}
$$

ロイシンが脫炭酸作用を行ひてィソ・フミルアネンとなり，直らに又炭酸と桔 合して㞸酸監を構成せること明なり。但し此實驗に於てはとの得量を記载せ支恐 らく收得量の甚だ惡しき事を想像するに難からす。

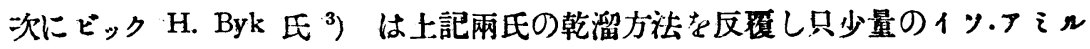

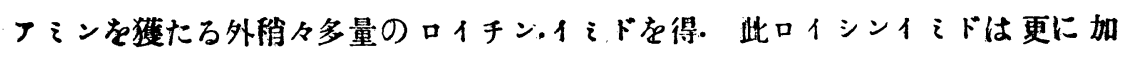
熱するもイソ.アネルフミンを化生せざるものなることを知れり.
1) Ann. 101, 296
2) Ann. 102, 224
3) D.R.P. 193166 . 
即ち此際の反應は 2 分子のロイシンより脫水作用によりてピベラチン核を構成 するものにして脫炭酸作用は行はれすとのことなり.
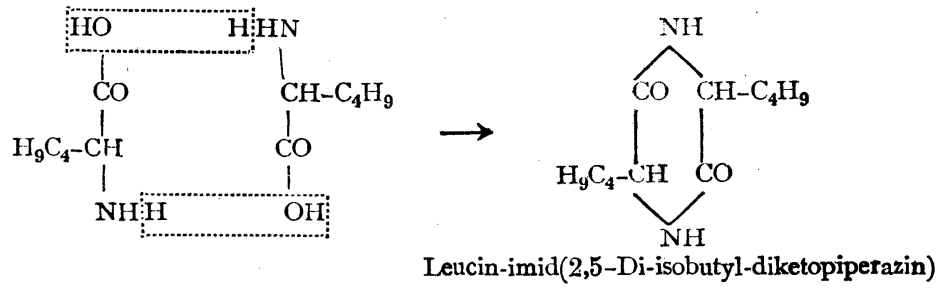

さればビック氏は常厌に於ける乾溜を避け異空内に於てロイシンを蒸溜するこ .とに改めイソ・アミルアミンの得量を多くするを得たりと云へり．但し此虑にも得 量率の記載なきを以て之を知るに由なく只常厣の際よりも成績良好なるへしと推 知するに過ぎす。

エルンスト・ワーゼル Ernst Waser 氏 $\left.{ }^{1}\right)$ (最近ロイシンの脫炎酸作用に關し群

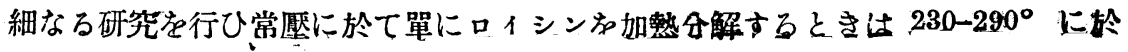

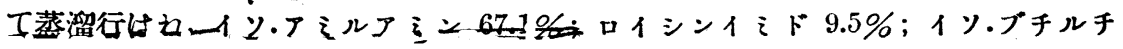
アニット $11.3 \%$ を得たる事を報告せり．而して此處に得たるイソ.ブチルチフニ ト Isobutylcyanid は分子内の脫水作用に基きて化生せるものなる事明なり・即ち

$$
\mathrm{CH}_{3}>\mathrm{CH}-\mathrm{CH}_{2}-\mathrm{CH}\left(\mathrm{NH}_{2}\right) \cdot \mathrm{COOH} \longrightarrow \mathrm{CH}_{3}>\mathrm{CH}-\mathrm{CH}_{2}-\mathrm{C} \equiv \mathrm{N}+2 \mathrm{H}_{2} \mathrm{O}
$$

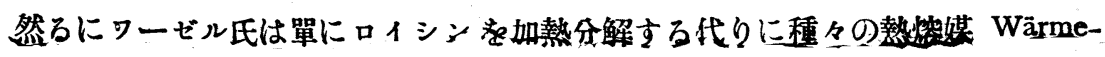
ueberträger 使田し亡反に其結果極め工良好にして上記の如ら副生物を認めす殆

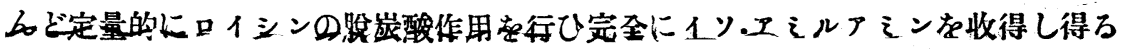
こるた睛證せり。

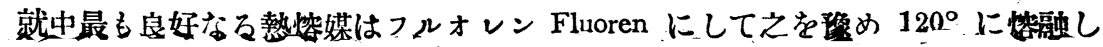

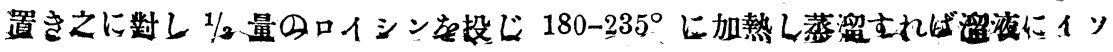

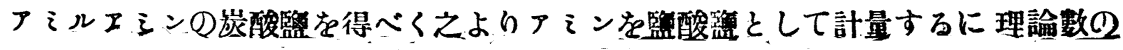
$97 \%$ 達すと云へり.

次にはチロシンの脫炭酸作用に就ても上記のワーゼル氏が精密なる 試鋃をロ シンと同時に施行し之を報告せり.

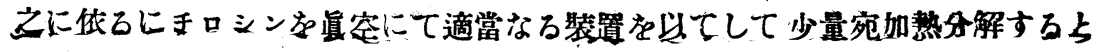

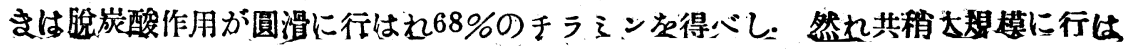

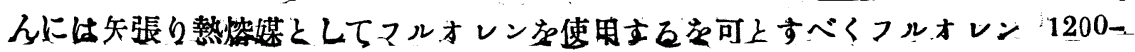

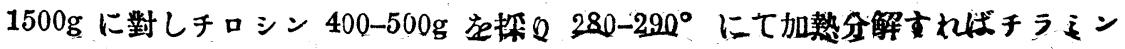
の收得率 90-96\%に達すべしと云へり.

1) Helv. chim. Acta, 8,758 . 
フルオレンに次ぐにヂフェニールメタン成績良く殆んどフルオレンに類似しフェ ナントレン. アントラチェン等之に次ぎチラミンの收得率 76-68\%を示せり・

チロシンよりチラiンの分解生成する反㗹は

$$
\mathrm{HO}(4) \mathrm{C}_{6} \mathrm{H}_{4}-\mathrm{CH}_{2}-\mathrm{CH}\left(\mathrm{NH}_{2}\right) \mathrm{COO}_{3} \mathrm{H} \rightarrow \mathrm{HO}[4] \mathrm{C}_{6} \mathrm{H}_{4}-\mathrm{CH}_{2}-\mathrm{CH}_{2}-\mathrm{NH}_{2}
$$

なるが,同時にロイシンの場合に於けるが如き副反應を生ずるや否やに就きてはワ 一ゼル氏の報告中毫も記載する所なし.

以上從來の文獻に於てワーゼル氏の報告は甚げ完全に近きものなりとは云へ同 氏の使用せる熱燃媒沉るフルオレンは坊間に之学求むること難く殊に我國にては 甚だ至難に屬し從つてワーゼル氏法を實地に施行する能はさる憾あり・

此に於て予等は他に容易に求め易き熱熔媒を搜索しロイシン並びにチロシンの.

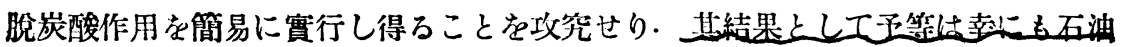

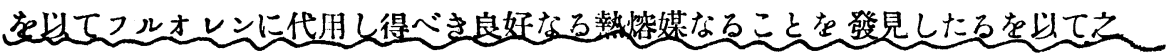
が葟驗報告を記載することとせとン

\section{實 驗 の 部}

先づロィシンの脫炭酸作用を實驗するに賞り熱跧媒として予等の試用したるも のはバラフィン, 流動バラフィン,アルファ・ナフチールアiン, ヂフェニールィタン 及び石油の 5 種なりき. 是等の熱熔媒中に一定量の乾燥口イシン芦段入燃融せし め一定温度にて蒸溜它行ひ溜出し來ろイソ.ア に溶解し監酸筒となし其濃厚溶液にアルカリを加へてア ルに振阷移行せしめ脫水後蒸溜に附し精製し其收得量在驗せり.

(1) パラフォン $40 \mathrm{~g}$, ロイシン $5 \mathrm{~g}$, 最高温度 $240^{\circ}$, 加熱時間 4 時間, 粗製アミン の得量 $1.5 \mathrm{~g}$ にして精製するに至らす。

(2) 流動パラフィン $80 \mathrm{cc}$, ロイシン $10 \mathrm{~g}$, 最高温度 $220^{\circ}$, 加熟時間 7 時間, 精製 アミンの得量 $2 \mathrm{~g}$ にして理論数の $30.1 \%$ \%當ろ.

(3) 流動バラフィン $80 \mathrm{cc}$, ロイシン $10 \mathrm{~g}$, 温度 $180^{\circ}$ より極めて徐々に高め $220^{\circ} に$ 止を，加熱時間 9 時間，精製アミンの得量 $3 \mathrm{~g}$ にして理論數の $45.1 \%$ \%當ろ.

（4）アルファ・ナフチールアミン $180 \mathrm{~g}$, ロ.イシン $23 \mathrm{~g}$, 像め熔融したる熱熔媒上に徐々 にロイシンか加人 $200^{\circ}$ より徐々に加熱し $240^{\circ}$ に至ろ. 加熱時間 15 時間, 精整

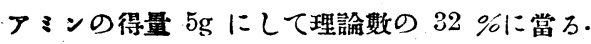

(5) ヂフェニールメタン $60 \mathrm{~g}$, ロインン $20 \mathrm{~g}$, 温度 $190^{\circ}$, 加熱時間 10 㻉間, 精製 アミンの得量 $3 \mathrm{~g}$ にてて理論数の $22.6 \%$ に當ろ.

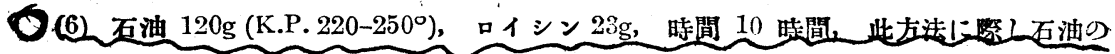

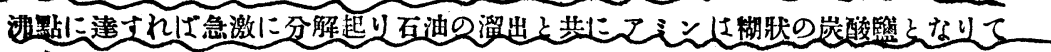

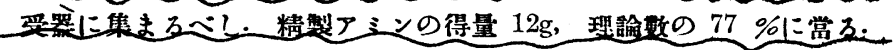


(7) 上記 (6)にては石油の沸點稍々高く一時に溜出し得さろの感あれば次には沸點の低

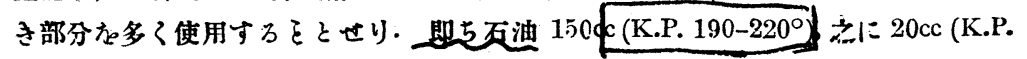

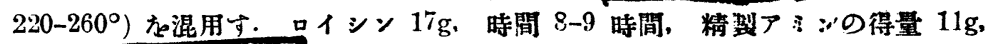

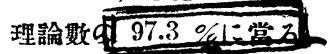

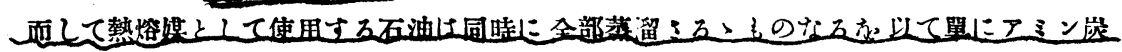

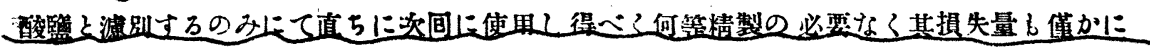
$3 \%$ 内外に止れ江.

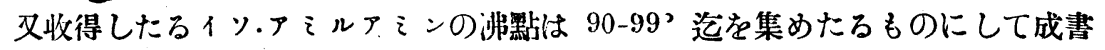
記載の如く 96-97’の恒數よりも沸點の開き大なれ共金復監及白金複監の熔點の 一致亚に白金複監の分析數の一致よりして何れも皆純粹なる物貿なりと認めた n.

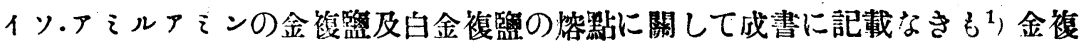

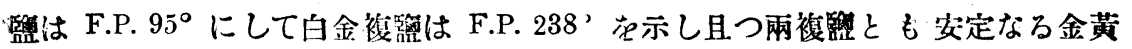
色結晶分なす。

分析 沸點 $\left(90-94^{\circ}\right)$ の部分より造りたる手複監 $[A]$ ；

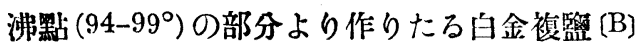
(A) 檢體 $0.1104 \mathrm{~g}$
白金量 $0.0368 \mathrm{~g}$
$33.33 \%$
(B) 檢體 $0.1220 \mathrm{~g}$
白金量 $0.0406 \mathrm{~g}$
$32.97 \%$
$\left(2 \mathrm{C}_{5} \mathrm{H}_{13} \mathrm{~N}+2 \mathrm{HCl}+\mathrm{PtCl}_{4}\right.$ として $)$
理論數
$33.42 \%$

以上余等の實驗に於て殊に(7)に示す如く一定温度の石油を熱熔媒として使用す るときは其結果ワーゼル氏のフルオンンの場合と同㨾の良成績を擧げ得ららのみ ならす石汕は極めて磨價に且つ容易に求め得べく更にフルオンンの加く特に精裂 を反覆するの必要なく每包新㶍なる溜液を使用し得る便あり. 何れより見るもつ ルオレンに優れるものなりと信ずるなり・

次にチロシンの脫炭酸作用に就ても亦予等は熱熔媒として石油を使用し得ぺき

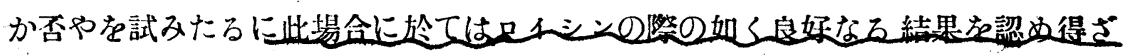
りし事は頗る遺憾なりき・然れ共使用せるチロシンの精製が容易ならず戗分不純 なりしに多少影琶ありしことな歪さ能はず。若し純粹のチロシンを以てせば收得 率を载分高め得たろなるべしと推察するものなり.

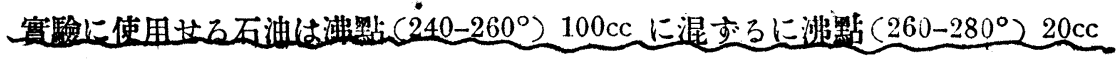

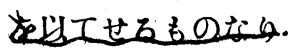

之をレトルトに容れ像め沸點近くまで加熱し置き別にチロシン $10 \mathrm{~g}$ を少訴の石 油に浮游覮捧せるものをその中に徐々に滴加し攪汼しつ」蒸溜を行ひたり。

1) Beilstein, 4, 180, Auflage IV 參照. 
然るときは $240^{\circ}$ の沸點に至る頃よりチロシンは分解し始め石油の蒸溜すると

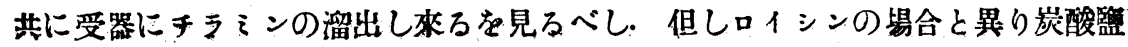
とならす遊権の監基のま」なりとす。約 5 時間にして蒸溜終りレトルトの底部に 幾分脂化せる殘渣を止むべし.

受器に得たるチラえンは之を稀監酸に溶解し脫色精製し紏白色の監酸監とせる に㩆點 $267^{\circ}$ を示せり.

\begin{tabular}{|c|c|c|c|}
\hline 第一间試驗 & 原料 $10 \mathrm{~g}$ & 監酸チラ ミン得量 & $5 \mathrm{~g}(52.17 \%)$ \\
\hline 第二间試驗 & 原料 $10 \mathrm{~g}$ & " & $5.5 \mathrm{~g}(57.39 \%)$ \\
\hline 第三回陚驗 & 原料 $10 \mathrm{~g}$ & " & $6.6 \mathrm{~g}(68.9 \%)$ \\
\hline
\end{tabular}

分析
I. 物筫 $0.1130 \mathrm{~g}$
$\mathrm{N}_{2}: 8.2 \mathrm{cc}\left(27.5^{\circ} 775.2 \mathrm{~mm}\right)$
N\% 7.95
II. 物筫 $0.1058 \mathrm{~g}$
$\mathrm{N}_{2}: 8.0 \mathrm{cc}\left(27.5^{\circ} 751 \mathrm{~mm}\right)$
N\% 8.161
$(\mathrm{OH}) \mathrm{C}_{6} \mathrm{H}_{4}-\mathrm{CH}_{2}-\mathrm{CH}_{2}-\mathrm{NH}_{2} \cdot \mathrm{HCl}$
理論數
$\mathrm{N} \% 8.071$

即ち余等の實驗に徵するに熱熔媒として石油を朋るチロシンの脫炭酸作用を行 ふときは理論數の絢 $70 \%$ チラてンを得ることを證し得たり.

昭和 2 年 9 月 20 日帝大葙學科度松教室

\section{アミノ酸及オキシ䤀の酸化（第一報）}

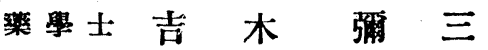

Y. Yoshiki : Ueber die Oxydation von Amino- und

Oxysäuren. (I). Oxydation von Leucinsäure.

緒 言

著者はつそノ酸及オキシ酸に對する酸化作用の關係名知らんと欲し種々の實驗 を施行したり．其結果を下に報告すべし.

本研笢に使用したる原料は植物性蛋白の加水分释座物にして著者は先つ之より 種々のアミノ酸を分取せん事を企てたり。蓋し一般にアミノ酸類は其儘に焀融せ

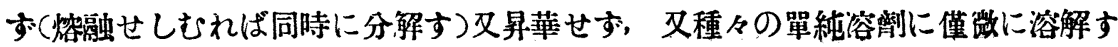
るに過ぎざるを以つて, 軖通に用ひらるろ分別法, 即蒸溜法, 昇華法, 再結晶法等に 依りてアぇノ酸の混合を分別し若くは不純アぇノ酸支精製すること能はす。. 此故

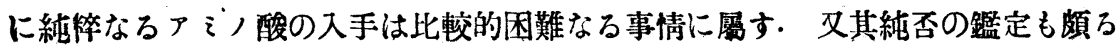
容易ならざるものの如く，アミ，酸自己の物理的恒數, 例へば比旋光度, 融點並に 溶解度等に關する交献の記載必声しも一義的なら方. 之社著者が先づナミ/酸の 製造並に精製等に意を用ひたる所以なり。 
heitlichen Krystalle aus Alkohol erhalten werden.

Dimethylapomorphin-jodmethylat wurde nach Ber. 35, 4387 ; 39, 3126 bereitet. Auf Grund obiger experimenteller Resultate wird hier die folgende Formel, aber unter Vorbehalt, vorgeschlagen, indem exaktere Schlussfolgerungen späteren Untersuchungen vorbehalten bleiben sollen :

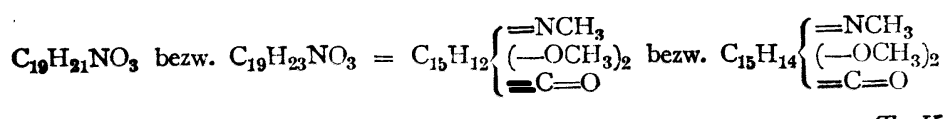

$$
\text { T. } K \text {. }
$$

S. Keimatsu und S. Yamamoto: Zur Decarboxylienung von Leucin und Tyrosin.

Ernst Waser ${ }^{1)}$ teilt mit, dass er zur Decarboxylierung von Leucin und Tyrosin verschiedene Wärmeüberträger verwendet und Fluoren die besten Resultate gegeben habe, indem aus Leucin Isoamylamin, aus Tyrosin Tyramin mit einer Ausbeute von 90-98\% der Theorie erhalten wurden.

Verf. haben nach leichter zugänglichen Wärmeüberträgern gefahndst und im Petroleum ein zweckentsprechendes Ersatzmittel gefunden.

Bei der Decarboxylierung von Leucin wurde ein Gemisch aus 150 cc Petroleum (K.P. 190-220 $)$ und 20 cc desselben (K.P. 220$260^{\circ}$ ) hergestellt und damit die Retorte beschickt; unter Umrühren wurden dann $17 \mathrm{~g}$ Leucin zugegeben und unter Erhitzen destilliert. Beim Siedepunkt des Petroleums trat eine plötzliche Zersetzung von Leucin ein und mit dem überdestillierenden Petroleum wurde in der Vorlage Isoamylamincarbonat erhalten. Das übergegangene Petroleum kann nach Trennung von Isoamylamincarbonat sofort zur nächsten Operation benutzt werden. Es wurden $11 \mathrm{~g}$ Isoamylamin als freie Base d.h. 97.3 \% der Theorie erhalten.

1) Helv. chim. Acta, 8, 758 (1926). 
Beim Tyrosin wurde auch zunächst ein Gemisch aus $100 \mathrm{cc}$. Petroleum (K.P. 240-260 $0^{\circ}$ ) und 29 cc desselben (K.P. 260-280 ${ }^{\circ}$ ) hergestellt und dasselbe in der Retorte vorher bis nahe seinem Kochpunkt erhitzt und dann unter Zutropfen einer Suspension von $10 \mathrm{~g}$ Tyrosin in wenig Petroleum destilliert. Das mit dem Petroleum ïbergegangene Tyramin wurde gereinigt und so wurden $6.6 \mathrm{~g}$ reines Tyramin d.h. nur $63.9 \%$ crhalten. Verf. erhoffen eine bessere Ausbeute bei Verwendung von genügend gereinigtem Ausgangsmaterial.

$T$. $K$.

Y. Yoshiki : Ueber die Oxydation von Anino- und Oxysäuren (I). Oxydation von Leucinsäure.

Verfasser hat zum Oxydieren von Leucinsäure das Jendrassik'sche Reagens verwendet. Im Jahre 1923 hat Jendrassik dasselbe d.h. Ferriferricyanid als Specialreagens für Vitamin B geeignet gefunden, da es mit dem letzteren eine specifische Farbreaktion gibt, die wahrscheinlich auf Oxydationsvorgängen beruht.

Doch hat bisher niemand eine Aufklärung über diesen Oxydationsvorgang versucht. Verfasser vermutet, dass das Jendrassik'sche Reagens bei seiner Oxydationswirkung im Sinne der drei unten bezeichneten Gleichungen reagiert d.h. es oxydiert unter Bildung von Berlinerblau, Turnbullsblau oder vom weissen Ferroferrocyanid oder diese drei Reaktionen finden auch gleichzeitig statt.

Die Klarstellung des obigen Reaktionsvorgangs wird auch für die Herstellung vom Jendrassik'schen Reagens dienlich sein, indem dadurch die dazu nötigen Mengenverhältnisse von Ferricyankalium und Ferrichlorid festgestellt werden.

I. $\left.6 \mathrm{~K}_{3}\left(\mathrm{FeCy}_{6}\right)+8 \mathrm{FeCl}_{3}+3 \mathrm{H}_{2}\right)-2 \mathrm{Fe}_{4}\left(\mathrm{FeC}_{6}\right)_{3}+18 \mathrm{KCl}+6 \mathrm{HCl}+\mathrm{O}_{3}$

II. $4 \mathrm{~K}_{3}\left(\mathrm{FeCl}_{6}\right)+6 \mathrm{FeCl}_{3}+3 \mathrm{H}_{2} \mathrm{O}=2 \mathrm{Fe}_{3}\left(\mathrm{FeC}_{\mathrm{y}_{6}}\right)_{2}+12 \mathrm{KCl}+6 \mathrm{HCl}+\mathrm{O}_{3}$

III. $2 \mathrm{~K}_{3}\left(\mathrm{FeCy}_{6}\right)+4 \mathrm{FeCl}_{3}+3 \mathrm{H}_{2} \mathrm{O}-2 \mathrm{Fe}_{2}\left(\mathrm{FeCy}_{6}\right)+6 \mathrm{KCl}+6 \mathrm{HCl}+\mathrm{O}_{3}$

Verf. hat zur Oxydation von Leucinsäure das Jendrassik'sche 